\title{
Advanced Oxidation Processes: Ozonation and Fenton Processes Applied to the Removal of Pharmaceuticals
}

\author{
Santana-Martínez Germán, Roa-Morales Gabriela, Solís-Casados Dora, \\ Romero Rubí, and Natividad Reyna \\ Contents \\ 1 Introduction \\ 2 Ozonation \\ 2.1 Fundamentals \\ 2.2 Technologies for Ozonation Applied to the Removal of Pharmaceutical Compounds \\ and Other Organic Molecules \\ 2.3 Pharmaceutical Compound Removal by Ozonation \\ 2.4 Pharmaceutical Compound Removal by Catalyzed Ozonation \\ 2.5 Pharmaceutical Compound Removal by Peroxonation \\ 2.6 Kinetics of Pharmaceuticals Removed by Ozonation \\ 2.7 Toxicity of Effluents Treated by Ozonation \\ 3 Fenton Process Applied to the Removal of Pharmaceutical Compounds \\ 3.1 Fenton Process Fundamentals \\ 3.2 Hydrogen Peroxide In Situ Production (Electrochemical and Photochemical \\ Methods) \\ 3.3 Pharmaceuticals Removed by Fenton \\ 4 Conclusions \\ References
}

\begin{abstract}
This chapter aims to present the fundamentals, important variables, and pharmaceuticals removed by ozonation and Fenton, which are only two of the current existing advanced oxidation processes. Some toxicological information regarding pharmaceuticals oxidized by ozonation is also included. Some strategies to improve such processes, like adding a catalyst, light, or electrical current, are also analyzed. Thus, this chapter intends to present general but fundamental aspects of the aforementioned processes.
\end{abstract}

\footnotetext{
S.-M. Germán, R.-M. Gabriela, S.-C. Dora, R. Rubí, and N. Reyna ( $ه)$

Centro Conjunto de Investigación en Química Sustentable UAEM-UNAM, Facultad de Química, Universidad Autónoma del Estado de México, Toluca, Estado de México, Mexico e-mail: reynanr@gmail.com
} 
Keywords Hydrogen peroxide, Hydroxyl radicals, Mineralization, Oxidation, Water remediation

\section{Introduction}

For centuries, the scientific and technological efforts of human being were mainly dedicated to provide comfort and make life "easier." In the last decades, however, it has been demonstrated that such a good intention while benefiting many has also had a detrimental effect on global environment, thus affecting the whole planet. This awareness of unsustainability has urged the development of processes not only for cleaner good production but also to clean the already contaminated industrial effluents and water bodies. In this context, pharmaceutical compounds have been identified as an important group of water pollutants, and therefore their removal by any means is imperative. To achieve so, advanced oxidation processes (AOPs) have emerged as an important alternative to eliminate them. Therefore, herein the fundamentals, advantages, and drawbacks of two important AOPs, ozonation and Fenton, are summarized. General aspects of variants of ozonation, like catalyzed ozonation and peroxonation, are revised too. The results of applying such processes to some pharmaceutical removal can also be found. The included pharmaceuticals were the most referenced ones in the last 5 years.

\section{Ozonation}

\subsection{Fundamentals}

The ozone molecule $\left(\mathrm{O}_{3}\right)$ possesses a high oxidant power $\left(E^{\circ}=2.07 \mathrm{~V}\right)$; it is highly reactive and finds a diversity of applications, mainly in the oxidation of organic/ inorganic compounds, disinfection, wastewater, and potable water treatment. Due to its reactivity, ozone tends to form oxygen. However, at some atmospheric conditions (like pressure, temperature, humidity, velocity) and $\mathrm{pH}$, the ozone half-life can be increased from seconds until days.

A limitation of ozonation is its inherent high cost to produce ozone at the point of use. Ozone production is mainly conducted by electrical discharge or electrolysis at industrial or laboratory scale [1].

Compound oxidation by ozone can be either through direct or indirect mechanisms. Although in practice both ways may take place simultaneously, it is necessary to specify the difference between the two routes as follows. 


\subsubsection{Indirect Reaction}

In this mechanism ozone is not the oxidant specie but helps to the generation of species that have an unpaired electron. This is possible under alkaline conditions, and under this condition is when ozonation can be considered an advanced oxidation process since it is based on the production of hydroxyl radicals. For a better explanation of this reaction path, it is necessary to consider three steps: initiation, chain propagation, and termination. The main reactions involved in these steps are summarized in Table 1. In summary, the main oxidant specie is the hydroxyl radical and not the ozone molecule.

In the first step, ozone reacts with hydroxide ions to generate superoxide anion $\left(\mathrm{O}_{2}^{-}\right)$and hydroperoxyl radical $\left(\mathrm{HO}_{2}^{*}\right)$. Some species from the first stage react once more with ozone to obtain new anions and radicals like the following: ozonide anion $\left(\mathrm{O}_{3}^{-}\right)$, hydrogen trioxide $\left(\mathrm{HO}_{3}^{-}\right)$, and hydroxyl radical $\left(\mathrm{OH}^{*}\right)$ which is the most powerful oxidant. The second stage is denominated chain reaction because of the regeneration of hydroperoxyl radicals on reaction (7), which also participates in reaction (2), so this promotes the chain reaction.

Moreover, hydroxyl radical can also react with some organic molecules $(\mathrm{R})$, and this is exemplified in reactions (8)-(11). In this route new species are formed like organic radicals $\left(\mathrm{R}^{\circ}\right)$, and when there is the presence of oxygen, peroxy radicals $\mathrm{ROO}^{\circ}$ can also be formed.

Unfortunately not all reactions allow to increase the amount of strong oxidants like in the stage of chain reaction. As a consequence of the reactivity of hydroxyl radicals with some organic/inorganic compounds, other anions that act as scavengers are generated. In this case, in reactions (12) and (13), carbonate/bicarbonate

Table 1 Ozone decomposition reactions [2]

\begin{tabular}{|c|c|c|}
\hline Step & \multicolumn{2}{|l|}{ Reaction } \\
\hline \multirow[t]{2}{*}{ Initiation } & $\mathrm{O}_{3}+\mathrm{OH}^{-} \rightarrow \mathrm{O}_{2}^{--}+\mathrm{HO}_{2}^{-}$ & $(1)$ \\
\hline & $\mathrm{HO}_{2}^{*} \leftrightarrow \mathrm{O}_{2}^{--}+\mathrm{H}^{+}$ & $(2)$ \\
\hline \multirow[t]{10}{*}{ Chain propagation } & $\mathrm{O}_{3}+\mathrm{O}_{2}^{\cdot-} \rightarrow \mathrm{O}_{3}^{\cdot-}+\mathrm{O}_{2}$ & (3) \\
\hline & $\mathrm{HO}_{3}^{\cdot} \leftrightarrow \mathrm{O}_{3}^{\cdot-}+\mathrm{H}^{+}$ & $(4)$ \\
\hline & $\mathrm{HO}_{3}^{*} \rightarrow \mathrm{OH}^{\bullet}+\mathrm{O}_{2}$ & $(5)$ \\
\hline & $\mathrm{OH}^{\bullet}+\mathrm{O}_{3} \rightarrow \mathrm{HO}_{4}^{-}$ & $(6)$ \\
\hline & $\mathrm{HO}_{4}^{*} \rightarrow \mathrm{O}_{2}+\mathrm{HO}_{2}^{*}$ & (7) \\
\hline & \multicolumn{2}{|c|}{ In presence of organic molecules $(\mathrm{R})$ : } \\
\hline & $\mathrm{H}_{2} \mathrm{R}+\mathrm{OH}^{\bullet} \rightarrow \mathrm{HR}^{\bullet}+\mathrm{H}_{2} \mathrm{O}$ & $(8)$ \\
\hline & $\mathrm{HR}^{\cdot}+\mathrm{O}_{2} \rightarrow \mathrm{HRO}_{2}^{*}$ & (9) \\
\hline & $\mathrm{HRO}_{2}^{\circ} \rightarrow \mathrm{R}+\mathrm{HO}_{2}^{-}$ & $(10)$ \\
\hline & $\mathrm{HRO}_{2}^{*} \rightarrow \mathrm{RO}+\mathrm{OH}^{\bullet}$ & $(11)$ \\
\hline \multirow[t]{3}{*}{ Termination } & $\mathrm{OH}^{\cdot}+\mathrm{CO}_{3}^{2-} \rightarrow \mathrm{OH}^{-}+\mathrm{CO}_{3}^{\cdot-}$ & $(12)$ \\
\hline & $\mathrm{OH}^{\bullet}+\mathrm{HCO}_{3}^{-} \rightarrow \mathrm{OH}^{-}+\mathrm{HCO}_{3}^{\cdot}$ & $(13)$ \\
\hline & $\mathrm{OH}^{\bullet}+\mathrm{HO}_{2}^{\cdot} \rightarrow \mathrm{O}_{2}+\mathrm{H}_{2} \mathrm{O}$ & $(14)$ \\
\hline Overall reaction & $3 \mathrm{O}_{3}+\mathrm{OH}^{-}+\mathrm{H}^{+} \rightarrow 2 \mathrm{OH}^{\bullet}+4 \mathrm{O}_{2}$ & $(15)$ \\
\hline
\end{tabular}


appears to quench the chain reaction; these ions are produced initially from $\mathrm{CO}_{2}$ dissolved into the water, which tends to form carbonic acid; as a consequence this acid is partially dissociated to carbonate, and a second dissociation forms ion bicarbonate. Reaction (15) is the result of combining the first reactions (1)-(7).

\subsubsection{Direct Oxidation Reaction}

Another path for the ozone decomposition is the direct reaction or also so-called Criegee mechanism, which consists of selective reactions between the ozone molecules with an unsaturated bond. In this mechanism the degree of nucleophilicity is determinant; for that reason, the reactivity of ozone molecule increases when there is the presence of saturate aliphatic or aromatic compounds. The oxidation is slower in the presence of unsaturated aliphatic, non-dissociated, and dissociated organic compounds.

On the other hand, with respect to the inorganic compounds, sometimes these can react much faster than organic compounds. More or less in the same way this happens with its degree of nucleophilicity. On the contrary, ionized or dissociated inorganic compounds can react faster with ozone [2]. This type of oxidation is favored under acidic reaction conditions.

\subsection{Technologies for Ozonation Applied to the Removal of Pharmaceutical Compounds and Other Organic Molecules}

The removal of pollutants in solution by ozonation implies the use of multiphase reactors in order to efficiently contact gas and liquid and even solid if the use of a heterogeneous catalyst is on demand. Thus, at this point, it is worth highlighting the importance of the reactors in ozonation process and also pointing out the most significant factors to be taken into account in their operation and design.

According to existing literature [3-5], semi-batch upflow bubble column is the preferred reactor to carry out the ozonation of pharmaceutical compounds. This reactor mainly consists of a cylindrical bubble column with a gas diffusor at the bottom where the ozone stream is fed. Ozone is produced from the decomposition of oxygen or air by an ozone generator; thus, the reactor feed stream is usually a mixture of ozone and air or oxygen since the effectiveness of ozone generation is not $100 \%$. This reactor is batch regarding the liquid phase and semi-batch regarding the gas phase, and this is to be considered in the transport balances used for design. Since $\mathrm{O}_{3}$ can be highly toxic, a common characteristic among ozonation reactors is that the outlet gas line of the reactor is connected to a trap with KI solution, in order to destroy the unconsumed ozone. To enhance the gas-liquid mass transfer, the 

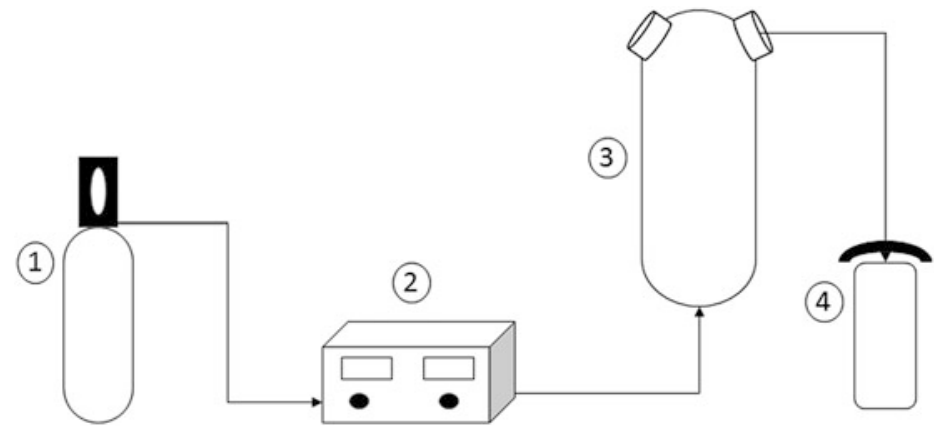

Fig. 1 Semi-batch ozonation system. Description: (1) oxygen, (2) ozonator, (3) upflow bubble column reactor, (4) KI trap

reactor is coupled to a magnetic stirring apparatus [6]. Figure 1 depicts a typical setup of an upflow bubble column reactor [7].

A variant of the reactor depicted in Fig. 1 is the semicontinuous reactor that has also been utilized to conduct the catalyzed ozonation of industrial effluents [810]. The main difference with a typical semi-batch reactor is the recirculation of liquid phase by a pump; the other elements are basically the same. An advantage of this kind of systems is the increase of volume, which allows working at pilot scale. In this context, a rather novel proposal was made by Crousier et al., who tested the TOCCATA $^{\circledR}$ catalyst in the treatment on urban wastewater [9]. In this work the reactor consisted of two bubble columns, one column was packed with the catalyst $\left(\right.$ TOCCATA $^{\circledR}$ ) and the other remained empty. This arrangement allowed the wastewater to be treated in both columns.

In any type of upflow bubble columns, special care should be taken with the particle size and density of the catalyst and gas flow rate. If the adequate values of these variables are not used, the catalyst will not be properly fluidized, and thus mass transfer would be the limiting step, and catalyst would be subdued.

Although the destruction of ozone is carried out in the trap of KI of the semibatch and semicontinuous reactors, it still has the disadvantage of wasting ozone, because this gas is continuously supplied to the reactor and its generation can be costly. Furthermore, in the aforementioned systems, the ozone destruction is not complete, and this is another disadvantage because of ozone undesirable effects [11]. This has motivated the design of new ozonation reactors like the one proposed by Lucas et al. [12]. Such a reaction system was called multi-orifice oscillatory baffled column (MOBC). Its design of several orifices in each baffle allows a reduction in the volume reactor and intensifies the ozonation process. To test the efficiency of this reactor, the degradation of p-hydroxybenzoic (p-HBA) acid was carried out [12] and was also benchmarked against a conventional bubble column. The reaction conditions were a total volume reaction of $9.6 \mathrm{~L}$, liquid flow rate of $4 \mathrm{~L} / \mathrm{min}, \mathrm{pH} 10 \pm 0.1$, gas flow rate of $2.1-4.7 \mathrm{~L} / \mathrm{min}$ with ozone concentration of $23 \mathrm{gO}_{3} / \mathrm{m}^{3}$, and $50 \mathrm{mg} / \mathrm{L}$ of $\mathrm{p}-\mathrm{HBA}$. Main results reported of this investigation were an increase of $20 \%$ of p-HBA degradation, $75 \%$ in the rate of mineralization per 
mole of ozone consumed, and the increase from 4.5 to 5 times of rate of mineralization per mole of ozone supplied. All these results are compared with those obtained in a conventional bubble column. It is well known that one baffle may increase dissolved oxygen concentration in water up to six times [13]. Additionally, the use of several baffles along the column allows a better distribution of the bubbles and the complete ozone consumption.

In this sense, another promising technology is the cocurrent downflow bubble column (CDBC) that has been successfully applied to conduct heterogeneous catalyzed hydrogenation and UV photo-catalyzed processes [14-16]. The main difference with the aforementioned reactors is that both phases, gas and liquid, are fed at the column top.

\subsection{Pharmaceutical Compound Removal by Ozonation}

$\mathrm{O}_{3}$ molecule high oxidant power and also the oxidant radicals produced during its decomposition have been applied for the removal of several compounds. Although there are many other pharmaceutical compounds that have been attempted to be degraded by ozone, Table 2 summarizes the ones that have been mostly reported.

It is worth noticing that the initial concentrations of the pharmaceutical compounds are rather low and this is because many of them have been shown [18, 20$25]$ to represent a biological hazard even at very low concentrations. It can also be observed that a complete mineralization is not reached in some cases. This may be due to the low ozone dosage, but also one should not forget the effect of the alkalinity produced by carbonated and bicarbonates, which tend to be scavengers of the hydroxyl radical. On the other hand, despite that mineralization is not

Table 2 Ozonation applied to removal of pharmaceutical compound

\begin{tabular}{l|l|l|l}
\hline Pharmaceutical & Reaction conditions & Removal $(\%)$ & References \\
\hline Carbamazepine (CBZ) & Ozone dosage: & LC-MS: 100 & {$[17]$} \\
Diclofenac (DCF) & $1.6 \mathrm{mg} / \mathrm{L}$ & LC-MS: 100 & \\
Sulfamethoxazole (SMX) & $2.3 \mathrm{mg} / \mathrm{L}$ & LC-MS: 100 & \\
Trimethoprim (TMP) & $2.8 \mathrm{mg} / \mathrm{L}$ & LC-MS: 100 & \\
& $4.5 \mathrm{mg} / \mathrm{L}$ & & \\
& $\mathrm{C}_{0}=5 \mathrm{mg} / \mathrm{L}$, for each compound & & \\
\hline Indomethacin (IM) & {$\left[\mathrm{O}_{3}\right]: 35 \mathrm{mg} / \mathrm{L}$} & TOC $~ 50$ & {$[18]$} \\
& Flow rate: $250 \mathrm{~mL} / \mathrm{min}$ & & \\
& $\mathrm{pH}: 7$ & & \\
\hline Mixture: & $\mathrm{C}_{0}: 25 \mu \mathrm{M}$ & & \\
Atenolol (ATL) & Time: $30 \mathrm{~min}$ & TOC $~ 35$ & {$[19]$} \\
Hydrochlorothiazide (HCT) & {$\left[\mathrm{O}_{3}\right]: 2.5 \mathrm{mg} / \mathrm{L}$} & & \\
Ofloxacin (OFX) & Flow rate: $36 \mathrm{~L} / \mathrm{h}$ & & \\
Trimethoprim (TMP) & $\mathrm{C}_{0}: 2.5 \mathrm{mg} / \mathrm{L}$ & & \\
\hline & Time: $120 \mathrm{~min}$ & & \\
\hline
\end{tabular}


complete, in several cases like mentioned earlier, by-products are less harmful, with respect to parent compounds. Thus, in those cases where mineralization is not complete, it is desirable to establish the toxicology of the treated solution in order to elucidate weather or not the ozone treatment is effective in oxidizing the organic compounds into less toxic ones. Ozone concentration can be low either because of inherent limitations of the system or mainly because ozonation may become rather expensive due to the high consumption of energy and type of technology to generate it. Thus, to reduce the cost of treatment, the most of ozone applications tend to employ low concentrations of this oxidant.

Regarding $\mathrm{pH}$, during ozonation this parameter is usually adjusted to a neutral value in order to promote the two mechanisms of ozone attack.

In order to increase removal efficiency and reduce the amount of ozone usage, there are reported some successfully assessed approaches. One is the addition of catalysts and the other one is the addition of hydrogen peroxide (peroxonation). The following two sections deal with such processes.

\subsection{Pharmaceutical Compound Removal by Catalyzed Ozonation}

The ozonation process can be enhanced by the addition of a catalyst, which can be homogeneous or heterogeneous. In the former case, this material must be a transition metal that can be oxidized and reduced back to initial state, but this kind of catalyst is not used in several applications because its recovery is rather difficult. For that reason, the most employed catalyst is the heterogeneous [26, 27]. Considering this, it is easy to identify when the ozonation is heterogeneously catalyzed, because chemisorption reactions between ozone - catalytic surface - organic molecule occur simultaneously [28].

In this process, there are several variables that affect the efficiency of the process. These are $\mathrm{pH}$, ozone dosage, stirring, temperature, type, concentration, and size of the catalyst. Stirring and particle size are particularly important when the efficiency of two catalysts are to be compared since in order to have a reflection of the catalytic surface, the whole process should be free of transport phenomena resistances. These variables are also important in order to avoid catalyst subutilization. Stirring is the first variable to be assessed since will not affect only the mass transfer from the solution to the catalyst but also from the ozone to the bulk solution and therefore to the catalyst. Particle size effect should also be discriminated since the very beginning. A particle size lower than $60 \mu \mathrm{m}$ usually guarantees the elimination of intra-particle transport resistances. Regarding $\mathrm{pH}$, when its value increases, the ozone is decomposed into hydroxyl radicals which are more reactive than ozone and less selective [7]; it also affects the surface of catalyst and the dissociation of organic pollutants in water [29]. If the $\mathrm{pH}$ value is low, ozone exists in water in a molecular state [30]. In acid medium, the oxidation of 
contaminants is by molecular ozone oxidation and not by hydroxyl radicals. Optimal values of $\mathrm{pH}$ have been obtained in neutral or alkaline medium $[27,31]$. Based on reactions (12) and (13), it is clear that carbonate ions are scavengers much stronger than bicarbonate ions. The increase of these ions is by addition of $\mathrm{Na}_{2} \mathrm{CO}_{3}$; this is common in dyes containing effluents [32]. If the HO${ }^{\circ}$ scavengers are present in the process, the molecular ozonation might prevail. Other $\mathrm{HO}^{\bullet}$ scavengers are phosphate and tert-butanol, the former blocks the Lewis site of catalyst [27], the latter reacts in bulk solution with $\mathrm{HO}^{\bullet}$ [33]. The presence of tertbutanol reduces the percentage of mineralization even more than $20 \%$.

The addition of catalyst increases the number of active sites, but not always higher dosages of catalysts increase the removal of pollutant. This is why this process is not always an alternative to not catalyzed ozonation, despite reducing ozone flow rate and its concentration.

Table 3 shows typical assessed variables and their values applied to the pharmaceutical removal by catalyzed ozonation. The shown pharmaceuticals were selected because they represent an important portion of the existing literature.

Table 3 Catalyzed ozonation applied to the removal of pharmaceutical compounds

\begin{tabular}{|c|c|c|c|}
\hline Pharmaceutical & Reaction conditions & Removal (\%) & References \\
\hline Sulfamethoxazole (SMX) & $\begin{array}{l}\text { Catalyst: } \mathrm{Fe}_{3} \mathrm{O}_{4} \\
\text { Catalyst dosage: } 0.3 \mathrm{~g} / \mathrm{L} \\
{\left[\mathrm{O}_{3}\right]: 2 \mathrm{~g} / \mathrm{h}} \\
\mathrm{pH}: 7 \\
\mathrm{C}_{0}: 50 \mathrm{mg} / \mathrm{L} \\
\text { Time: } 5 \mathrm{~min}\end{array}$ & 100 & [34] \\
\hline Phenacetin (PNT) & $\begin{array}{l}\text { Catalyst: } \mathrm{CuFe}_{2} \mathrm{O}_{4} \\
\text { Catalyst dosage: } 2.0 \mathrm{~g} / \mathrm{L} \\
{\left[\mathrm{O}_{3}\right]: 0.36 \mathrm{mg} / \mathrm{min}} \\
\text { pH: } 7.72 \\
\mathrm{C}_{0}: 0.2 \mathrm{mM} \\
\text { Time: } 5 \mathrm{~min} \\
\text { Time: } 3 \mathrm{~h} \text { (mineralization) }\end{array}$ & $\begin{array}{l}100 \\
\text { TOC: } 90\end{array}$ & [35] \\
\hline Sulfamethazine & $\begin{array}{l}\text { Catalyst: } \mathrm{Cu}_{0.1} \mathrm{Fe}_{0.9} \mathrm{OOH} \\
\text { Catalyst dosage: } 0.2 \mathrm{~g} / \mathrm{L} \\
{\left[\mathrm{O}_{3}\right]: 15 \mathrm{mg} / \mathrm{min}} \\
\mathrm{pH}: 7 \\
\mathrm{C}_{0}: 20 \mathrm{mg} / \mathrm{L} \\
\text { Time: } 10 \mathrm{~min} \\
\text { Time: } 120 \mathrm{~min} \text { (mineralization) }\end{array}$ & $\begin{array}{l}100 \\
\text { TOC: } 44\end{array}$ & [36] \\
\hline Ibuprofen & $\begin{array}{l}\text { Catalyst: } \mathrm{Fe}_{2} \mathrm{O}_{3} / \mathrm{Al}_{2} \mathrm{O}_{3} @ \mathrm{SBA}-15 \\
\text { Catalyst dosage: } 1.5 \mathrm{~g} / \mathrm{L} \\
{\left[\mathrm{O}_{3}\right]: 30 \mathrm{mg} / \mathrm{L}} \\
\text { Flow rate: } 0.2 \mathrm{~L} / \mathrm{min} \\
\text { pH: } 7 \\
\mathrm{C}_{0}: 10 \mathrm{mg} / \mathrm{L} \\
\text { Time: } 60 \mathrm{~min}\end{array}$ & $\begin{array}{l}90 \\
\text { TOC: } 26\end{array}$ & [37] \\
\hline
\end{tabular}




\subsection{Pharmaceutical Compound Removal by Peroxonation}

In order to enhance ozonation action, $\mathrm{H}_{2} \mathrm{O}_{2}$ instead of a catalyst can be added to the reacting system, and this process is known as peroxonation. The added reactions of this process are presented below. In summary, these reactions imply that the interaction $\mathrm{H}_{2} \mathrm{O}_{2} / \mathrm{O}_{3}$ can be affected by other species like water, as can be seen in reaction (16) where water is partially dissociated into hydroxide anions. This ion can also react with ozone (reaction 18), obtaining a hydroxyl radical, which is also produced by reaction (17).

$$
\begin{aligned}
\mathrm{H}_{2} \mathrm{O}_{2}+\mathrm{H}_{2} \mathrm{O} & \rightarrow \mathrm{HO}_{2}^{-}+\mathrm{H}_{3} \mathrm{O}^{+} \\
\mathrm{H}_{2} \mathrm{O}_{2}+2 \mathrm{O}_{3} & \rightarrow 2 \mathrm{OH}^{\cdot}+3 \mathrm{O}_{2} \\
\mathrm{O}_{3}+\mathrm{HO}_{2}^{-} & \rightarrow \mathrm{OH}^{\bullet}+2 \mathrm{O}_{2}
\end{aligned}
$$

Some pharmaceutical compounds that have been removed by peroxonation are in Table 4. Reaction conditions and removal efficiency are also included.

Gomes and collaborators $[18,21,39]$ have reported that when more than $10 \mathrm{mM}$ of hydrogen peroxide is used, this reagent and ozone can act as radical scavengers, and their addition may be detrimental rather than helpful. This phenomenon occurs by the following reactions (19) and (20):

$$
\begin{gathered}
\mathrm{OH}^{\bullet}+\mathrm{H}_{2} \mathrm{O}_{2} \rightarrow \mathrm{HO}_{2}^{\bullet}+\mathrm{H}_{2} \mathrm{O} \\
\mathrm{OH}^{\bullet}+\mathrm{O}_{3} \rightarrow \mathrm{HO}_{2}^{\bullet}+\mathrm{O}_{2}
\end{gathered}
$$

The products of these reactions are radicals with lower oxidant power than hydroxyl radicals. Thus $\mathrm{H}_{2} \mathrm{O}_{2}$ concentration must be kept at low values to prevent its action as scavenger. Regarding $\mathrm{pH}$ values, these are preferred neutral.

Table 4 Peroxonation applied to removal of pharmaceutical compounds

\begin{tabular}{l|l|l|l}
\hline & $\begin{array}{l}\text { Reaction } \\
\text { conditions }\end{array}$ & $\begin{array}{l}\text { Removal } \\
(\%)\end{array}$ & References \\
\hline Fluoxetine & {$\left[\mathrm{O}_{3}\right]: 30 \mathrm{mg} / \mathrm{L}$} & 86.14 & {$[38]$} \\
& {$\left[\mathrm{H}_{2} \mathrm{O}_{2}\right]: 0.02 \mathrm{mM}$} \\
$\mathrm{C}_{0}: 50 \mathrm{mg} / \mathrm{L}$ & & \\
Time: $20 \mathrm{~min}$ & & \\
& {$\left[\mathrm{O}_{3}\right]: 20 \mathrm{mg} / \mathrm{L}$} & 100 & {$[21]$} \\
\hline Sulfamethoxazole (SMX) and Diclofenac & {$\left[\mathrm{H}_{2} \mathrm{O}_{2}\right]: 5 \mathrm{mM}$} & COD: 91 & \\
pHCF) & $\mathrm{CH}_{0}: 88.5 \mathrm{mg} / \mathrm{L}$ & & \\
& Time: $120 \mathrm{~min}$ & & \\
& & & \\
\hline
\end{tabular}




\subsection{Kinetics of Pharmaceuticals Removed by Ozonation}

Based on bench-scale studies, in general it is necessary to consider the kinetic study with the purpose of understanding the behavior of reactors at full scale [40]. All cases presented in this chapter used the following method to establish the reaction rate and kinetic constant, considering the data obtained from the profile degradation of the main pollutant and is known as integral method. The following equation can be integrated, assuming an $n$th pseudo-order reaction,

$$
r_{1}=-\frac{d C}{d t}=k_{\mathrm{obs}} C^{n}
$$

In most of the cases, this order has been found to be 1 or 2 for most of pharmaceuticals [21, 41]. When Eq. (21) is integrated assuming either order 1 or order 2 , the resulting equations are (22) and (23), respectively.

$$
\begin{gathered}
\frac{\ln C_{0}}{\ln C_{t}}=k_{\mathrm{obs}} t \\
\frac{1}{C_{t}}-\frac{1}{C_{0}}=k_{\mathrm{obs}} t
\end{gathered}
$$

Sometimes in the aforementioned equations, mineralization data from analysis of COD or TOC can also be employed. In the ozonation process, the kinetic study is focused on the determination of reactivity of ozone in direct and indirect form. To achieve so, the kinetic constants respect to ozone $\left(k_{\mathrm{O} 3}\right)$ and hydroxyl radical $\left(k_{\mathrm{HO}}\right)$ are calculated. Generally speaking, in the degradation of pharmaceuticals like trimethoprim, valsartan, furosemide, lidocaine, tramadol, and fluconazole between others, the reported kinetic constants are in the order of $1-10^{7} \mathrm{M}^{-1} \mathrm{~s}^{-1}$ with respect to the ozone and for hydroxyl radical in the order of $1 \times 10^{8}-10^{10} \mathrm{M}^{-1} \mathrm{~s}^{-1}[18,21,31]$. Despite several studies employing distillated water, this behavior can be extrapolated to other water matrix. The nature of nonselective oxidant of hydroxyl radical allows that their kinetic constants are higher than ozone. The study of [42] determined that pharmaceutical compounds with aromatic ring show high reactivity $\left(\sim 10^{4}-10^{7} \mathrm{M}^{-1} \mathrm{~s}^{-1}\right)$, while saturated aliphatic compounds present a very low reactivity $\left(<5 \mathrm{M}^{-1} \mathrm{~s}^{-1}\right)$.

\subsection{Toxicity of Effluents Treated by Ozonation}

In all water treatments, the aim is to remove contaminants either by chemical reduction or oxidation. In the latter, near complete mineralization is usually taken as an indicative of the treated effluent that can be safely discharged. This, however, is not always a guarantee [43]. This is due to the generation of species more harmful than the parent compound and to the addition of chemicals for changing $\mathrm{pH}$, for example. In this section a variety of tests that have been applied to the effluents treated by ozonation is presented. 
Within literature, it can be observed that toxicity removal directly depends on ozone dosage. For instance, working at high ozone dosages, toxicity can be eliminated at $100 \%$, this was demonstrated with the indomethacin ozonation where several ozone concentrations were assessed and toxicity was estimated by means of essays with a luminescent bacterium called Photobacterium phosphoreum. Authors report that $35 \mathrm{mg} / \mathrm{L}$ of ozone concentration is enough to eliminate the toxicity after $60 \mathrm{~min}$ [18]. According to this investigation, it is not necessary to mineralize all organic matter; in fact the TOC removal is almost 50\%. Some by-products that remain are essentially chloride and organic acids (acetic, formic, and oxalic). Oxalic acid, however, has been demonstrated to be highly toxic when biological hazard is established by means of other essays, with Lactuca sativa, for example.

Ecotoxicity tests can also be simultaneously conducted by some microbiological tests and can be corroborated with a software. In fact ECOSAR program (version 1.11), developed by USEPA, has been applied in the study of ofloxacin (OFX) ozonation, specifically on the determination of its hazard indices on green algae, daphnia, and fish [5]. Based on the proposed mechanism for the OFX degradation, 14 by-products were identified, which most of them after the treatment are not harmful, but when is exposed until $96 \mathrm{~h}$, some by-products like OFX 336A and OFX 364 present a high chronic toxicity. In such study, ozone concentration was $15 \mathrm{mg} / \mathrm{L}$ in the flow rate.

As can be seen from the results presented above, the increase of ozone concentration increases the efficiency of toxicity removal. Such concentration, however, may be so high than the process cost that significantly increases too. In this case, adding a catalyst might be practical. Specifically, the group of Fei Qi and Zhonglin Chen, has tested the molecule of bezafibrate (BZF) with two different catalysts $[39,44]$. In one study, these investigators employed $50 \mathrm{mg} / \mathrm{L}$ of a catalystdenominated cobalt-doped red mud $(\mathrm{Co} / \mathrm{RM})$, with $0.5 \mathrm{mg} / \mathrm{L}$ of ozone concentration to remove $2.76 \mu \mathrm{M}$ of BZF. Toxicity assessment was evaluated by Chlorella vulgaris, which presented a $96 \mathrm{~h}-\mathrm{EC}_{50}$ of $63 \%$. In a second study, the reaction conditions, toxicity tests, and pollutant of the first study were kept constant; the only difference was the catalyst, where instead of cobalt cerium (IV), (Ce (IV)/RMp) was employed and more than $50 \%$ of detoxification in $96 \mathrm{~h}-\mathrm{EC}_{50}$ test was attained. Still, toxicity was not fully eliminated when using the catalyst. A similar problem is observed during the peroxonation process. This can be ascribed to the addition of hydrogen peroxide whose excess must be quenched with catalase solution.

Sulfamethoxazole and diclofenac were studied by Rui Martins' group [21]; from this investigation, they assessed the removal of both pollutants in a synthetic solution and also from a secondary effluent by peroxonation. The toxicity was evaluated by a procedure described in ISO/DIS11348/3, which employs marine bacteria called Vibrio fischeri and measures the percentage on inhibition of light emission. Using this method, the samples of these water matrices (synthetic and secondary effluent) were analyzed; after $2 \mathrm{~h}$ of peroxonation, results are the following: the inhibition was $29 \%$ and $38 \%$, for secondary effluent and synthetic solution, respectively. 


\section{Fenton Process Applied to the Removal of Pharmaceutical Compounds}

\subsection{Fenton Process Fundamentals}

Fenton reaction (24) is named after H.J.H. Fenton who added $\mathrm{Fe}^{2+}$ ions to catalyze the decomposition of $\mathrm{H}_{2} \mathrm{O}_{2}$ into hydroxyl radicals, hydroxyl ions, and $\mathrm{Fe}^{3+}$ ions and to intensify, in this way, tartaric acid oxidation.

$$
\mathrm{Fe}^{2+}+\mathrm{H}_{2} \mathrm{O}_{2} \rightarrow \mathrm{Fe}^{3+}+\mathrm{OH}^{\bullet}+\mathrm{OH}^{-}
$$

This reaction depends strongly on $\mathrm{pH}$ values, specifically on the ratio $\mathrm{Fe}^{2+} / \mathrm{Fe}^{3+}$ $\left(E^{\circ}=0.77 \mathrm{~V} / \mathrm{SHE}\right)$. The best results to dissociate hydrogen peroxide toward hydroxyl radicals have been reported in the range of 2.8-3 of $\mathrm{pH}[45,46]$. Taking into account that in acidic media Fenton's reaction presents better results, similar reactions occur simultaneously (25). When $\mathrm{Fe}^{3+}$, decompose hydrogen peroxide is so-called Fenton reaction (26) and tends to form hydroperoxyl radicals, and by means of this reaction, the catalytic ion $\mathrm{Fe}^{2+}(27)$ is regenerated.

$$
\begin{gathered}
\mathrm{Fe}^{2+}+\mathrm{H}_{2} \mathrm{O}_{2}+\mathrm{H}^{+} \rightarrow \mathrm{Fe}^{3+}+\mathrm{OH}^{\cdot}+\mathrm{H}_{2} \mathrm{O} \\
\mathrm{Fe}^{3+}+\mathrm{H}_{2} \mathrm{O}_{2} \rightarrow \mathrm{Fe}^{2+}+\mathrm{HO}_{2}^{\cdot}+\mathrm{H}^{+} \\
\mathrm{Fe}^{3+}+\mathrm{HO}_{2}^{\cdot} \rightarrow \mathrm{Fe}^{2+}+\mathrm{O}_{2}+\mathrm{H}^{+}
\end{gathered}
$$

The excess of Fenton's reagent $\left(\mathrm{Fe}^{2+} / \mathrm{H}_{2} \mathrm{O}_{2}\right)$ has been reported to inhibit the oxidant power of hydroxyl radical generating undesirable reactions (28)-(31) [47], through which scavenging species or oxidants with lower oxidant power are obtained. Additionally, working under neutral media, the reaction (30) takes place at this condition, and selective oxidants like high-valent ferryl-oxo species $\mathrm{Fe}^{(\mathrm{IV})}$ might be produced [48].

$$
\begin{gathered}
\mathrm{Fe}^{2+}+\mathrm{OH}^{\bullet} \rightarrow \mathrm{Fe}^{3+}+\mathrm{OH}^{-} \\
\mathrm{H}_{2} \mathrm{O}_{2}+\mathrm{OH}^{\bullet} \rightarrow \mathrm{HO}_{2}^{\cdot}+\mathrm{H}_{2} \mathrm{O} \\
\mathrm{OH}^{\cdot}+\mathrm{OH}^{\bullet} \rightarrow \mathrm{H}_{2} \mathrm{O}_{2} \\
\mathrm{Fe}^{2+}+\mathrm{H}_{2} \mathrm{O}_{2} \rightarrow \mathrm{Fe}^{(\mathrm{IV})} \mathrm{O}^{2+}+\mathrm{H}_{2} \mathrm{O}
\end{gathered}
$$

The main disadvantages of Fenton reaction are the storage and the risks of hydrogen peroxide; also the catalytic ion $\mathrm{Fe}^{2+}$ tends to oxidize toward $\mathrm{Fe}^{3+}$, which forms sludge or metal hydroxides (reactions 32 and 33) and $\mathrm{Fe}(\mathrm{III})$ carboxylic acids complexes [46, 49] and the acid $\mathrm{pH}[50]$. Nevertheless, some variants of this process are focused on generating hydrogen peroxide in situ, to minimize the process costs, disadvantages, and undesirable reactions abovementioned. Also, other than Fe salts have been used as source of catalyst. In this sense, iron-pillared clays have been successfully used and have considerably reduced the difficulty of recovering the catalyst [51]. Also, other metals, like cupper, have been successfully 
applied as catalysts of $\mathrm{H}_{2} \mathrm{O}_{2}$ dissociation [52]. In such a case, the process is called Fenton-like.

$$
\begin{aligned}
\mathrm{Fe}^{3+}+\mathrm{H}_{2} \mathrm{O}_{2} & \leftrightarrow \mathrm{Fe}^{\mathrm{III}}\left(\mathrm{HO}_{2}\right)^{2+}+\mathrm{H}^{+} \\
\mathrm{FeOH}^{2-}+\mathrm{H}_{2} \mathrm{O}_{2} & \leftrightarrow \mathrm{Fe}^{\mathrm{III}}(\mathrm{OH})\left(\mathrm{HO}_{2}\right)^{-}+\mathrm{H}^{-}
\end{aligned}
$$

\subsection{Hydrogen Peroxide In Situ Production (Electrochemical and Photochemical Methods)}

The oxidant power of hydrogen peroxide not only finds application in wastewater treatment; it can also be applied to organic synthesis and paper industry, like disinfectant [53]; in addition it is used as rocket fuel [54]. One of the main advantages that make of $\mathrm{H}_{2} \mathrm{O}_{2}$ an environmentally safe oxidant is the by-products (oxygen and water). To diminish the risk in the handling of this oxidant, some methods, like anthraquinone process [53], electrochemical process [55], and photocatalytic process [56], have been developed in the generation of hydrogen peroxide. Specifically the last two mentioned processes are preferred because of the low energetic costs and because it allows the $\mathrm{H}_{2} \mathrm{O}_{2}$ production at mild conditions and most of them are green technologies.

According to the electrochemical process, the hydrogen peroxide is produced mainly by oxygen reduction at the cathode in acidic/neutral media by the following reaction [55]:

$$
\mathrm{O}_{2(\mathrm{~g})}+2 \mathrm{H}^{+}+2 \mathrm{e}^{-} \rightarrow \mathrm{H}_{2} \mathrm{O}_{2}
$$

Table 5 summarizes the results of some investigations about this topic in which it can be observed that the carbonaceous materials are the most studied ones with respect to this process by the low cost and high concentrations electro-generated in electrochemical cells; it also requires an acidic media ( $\mathrm{pH} \mathrm{2-4)}$ and an electrolytelike sodium sulfate. On the other hand, in this kind of carbonaceous materials is not possible to employ high current intensities $(i>300 \mathrm{~mA})$, due to the material structure. However a variant of carbonaceous materials called gas diffusion [63] electrode (GDE) is also applied with success at undivided cells, even at pilot-scale (reactors type filter press) applications [64, 65] in the pharmaceutical removal (ranitidine and metronidazole). In such investigations the amount of $\mathrm{H}_{2} \mathrm{O}_{2}$ is not reported, but the mineralization is almost complete in volumes of $2.5 \mathrm{~L}$ and $10 \mathrm{~L}$, respectively. The main advantage of GDE is that it can simultaneously be applied to current intensity and flow rate of air/oxygen. GDE also is doped with other materials like $\mathrm{CeO}_{2}$ with the purpose of increasing the production of $\mathrm{H}_{2} \mathrm{O}_{2}$ [61] . Another material reported with a high concentration of hydrogen peroxide is the boron-doped diamond [57, 63], which has the advantage of support high current densities and overpotential oxygen. 
Table $5 \quad \mathrm{H}_{2} \mathrm{O}_{2}$ generated by electrolysis

\begin{tabular}{|c|c|c|c|}
\hline $\begin{array}{l}\text { Electro- } \\
\text { generated } \\
\mathrm{H}_{2} \mathrm{O}_{2} \\
(\mathrm{mg} / \mathrm{L})\end{array}$ & Reaction conditions & Observations & References \\
\hline 82 & $\begin{array}{l}\text { Anode: boron-doped diamond } \\
\text { Cathode: boron-doped diamond } \\
j: 31 \mathrm{~mA} / \mathrm{cm}^{2} \\
V=3 \mathrm{~L} \\
\text { Recirculation: } 12 \mathrm{~L} / \mathrm{min} \\
\text { Electrolyte: } 0.05 \mathrm{M} \mathrm{Na}_{2} \mathrm{SO}_{4} \\
\text { pH } 3 \\
\text { Time: } 180 \mathrm{~min}\end{array}$ & Reactor type filter press & [57] \\
\hline 116 & $\begin{array}{l}\text { Cathode: graphite felt } \\
\text { Anode: Pt } \\
\text { Rotating speed: } 10 \mathrm{rpm} \\
j: 50 \mathrm{~mA} / \mathrm{cm}^{2} \\
V=0.1 \mathrm{~L} \\
\text { Electrolyte: } 0.05 \mathrm{M} \mathrm{Na}_{2} \mathrm{SO}_{4} \\
\text { pH } 3 \\
\text { Time: } 60 \mathrm{~min}\end{array}$ & $\begin{array}{l}\text { Rotating reactor with } \\
\text { rotating disk anodes } \\
\text { Without oxygen aeration }\end{array}$ & {$[58]$} \\
\hline 472.9 & $\begin{array}{l}\text { Cathode: carbon black/PTFE } \\
\text { Anode: } \mathrm{Pt} \\
j: 5 \mathrm{~mA} / \mathrm{cm}^{2} \\
V=0.1 \mathrm{~L} \\
\text { Electrolyte: } 0.05 \mathrm{M} \mathrm{Na}_{2} \mathrm{SO}_{4} \\
\text { pH } 3 \\
\text { Time: } 60 \mathrm{~min}\end{array}$ & Without oxygen aeration & [59] \\
\hline 960 & $\begin{array}{l}\text { Cathode: modified carbon felt } \\
j: 50 \mathrm{~mA} / \mathrm{cm}^{3} \\
V=1 \mathrm{~L} \\
\text { Electrolyte: } 0.05 \mathrm{M} \mathrm{Na}_{2} \mathrm{SO}_{4} \\
\text { Time: } 180 \mathrm{~min}\end{array}$ & $\begin{array}{l}\text { Jet aerator } \\
\text { Does not require oxygen } \\
\text { supply }\end{array}$ & {$[60]$} \\
\hline 871 & $\begin{array}{l}\text { Working electrode: gas diffusion } \\
\text { electrode (GDE) with } 4 \% \text { of } \mathrm{CeO}_{2} / \mathrm{C} \\
\text { Counter electrode: } \mathrm{Pt} \\
\text { Reference electrode: } \mathrm{Ag} / \mathrm{AgCl}(\mathrm{KCl} \\
\text { sat) } \\
E:-2.3 \mathrm{~V} \\
V=250 \mathrm{~mL} \\
\text { Electrolyte: } \mathrm{NaOH} 1 \mathrm{M} \\
\text { Time: } 120 \mathrm{~min}\end{array}$ & Divided cell & {$[61]$} \\
\hline 240 & $\begin{array}{l}\text { Working electrode: modified (with } \\
\text { iron (II) phthalocyanine) GDE (gas } \\
\text { diffusion electrode) } \\
\text { Counter electrode: } \mathrm{Pt} \\
\text { Reference electrode: } \mathrm{Ag} / \mathrm{AgCl} \\
E:-1.0 \text { (vs Ag/AgCl } \\
V=400 \mathrm{~mL} \\
\text { Electrolyte: } 0.1 \mathrm{M} \mathrm{H}_{2} \mathrm{SO}_{4} \text { and } 0.1 \mathrm{M} \\
\mathrm{K}_{2} \mathrm{SO}_{4} \\
\text { Time: } 90 \text { min }\end{array}$ & $\begin{array}{l}\text { Divided cell } \\
\text { The presence of a modifier } \\
\text { induces an increase in ring } \\
\text { current }\end{array}$ & {$[62]$} \\
\hline
\end{tabular}


Table 5 (continued)

\begin{tabular}{|c|c|c|c|}
\hline $\begin{array}{l}\text { Electro- } \\
\text { generated } \\
\mathrm{H}_{2} \mathrm{O}_{2} \\
(\mathrm{mg} / \mathrm{L})\end{array}$ & Reaction conditions & Observations & References \\
\hline 9,371 & $\begin{array}{l}\text { Cathode: carbon black/PTFE } \\
j: 60 \mathrm{~mA} / \mathrm{cm}^{2} \\
V=20 \mathrm{~mL} \text { (cathodic cell) and } 40 \mathrm{~mL} \\
\text { (anodic cell) } \\
\text { Flow rate (air): } 40 \mathrm{~mL} / \mathrm{min} \\
\text { Electrolyte: } 0.2 \mathrm{M} \mathrm{Na}_{2} \mathrm{SO}_{4} \\
\text { pH } 4 \\
\text { Time: } 120 \mathrm{~min}\end{array}$ & $\begin{array}{l}\text { Divided cell (nafion 117) } \\
\text { Phenol }\left(\mathrm{C}_{0}: 100 \mathrm{mg} / \mathrm{L}\right) \\
\text { remotion } 100 \%(40 \mathrm{~min}) \\
\text { TOC removal } 85 \% \\
(120 \mathrm{~min})\end{array}$ & {$[20]$} \\
\hline 180.27 & $\begin{array}{l}\text { Anode: stainless steel } \\
\text { Cathode: reticulated vitreous carbon } \\
\text { (RVC) } \\
i: 170 \mathrm{~mA} \\
V=1 \mathrm{~L} \text { each compartment } \\
\text { Catholyte: } 0.05 \mathrm{M} \mathrm{Na}_{2} \mathrm{SO}_{4}, 0.01 \mathrm{M} \\
\mathrm{H}_{2} \mathrm{SO}_{4} \\
\text { Anolyte: } 0.8 \mathrm{M} \mathrm{H}_{2} \mathrm{SO}_{4} \\
\Delta \mathrm{E}_{\text {Cell: }} 2-3 \mathrm{~V} \\
\text { pH 2 } \\
\text { Time: } 180 \mathrm{~min}\end{array}$ & $\begin{array}{l}\text { Divided cell } \\
0.001 \mathrm{M} \mathrm{FeSO} \mathrm{O}_{4} \cdot 7 \mathrm{H}_{2} \mathrm{O} \text { in } \\
\text { the catholyte, for electro- } \\
\text { Fenton process } \\
90 \% \text { of discoloration for } \\
\text { blue basic } 9\left(\mathrm{C}_{0}: 0.08 \mathrm{mM}\right) \\
\text { at } 14 \text { min } \\
\text { Reactive black } 5\left(\mathrm{C}_{0}:\right. \\
0.063 \mathrm{mM}) \text { at } 90 \mathrm{~min} \\
\text { Acid orange } 7\left(\mathrm{C}_{0}:\right. \\
0.14 \mathrm{mM}) \text { at } 70 \mathrm{~min}\end{array}$ & [21] \\
\hline
\end{tabular}

More recently the investigation of undivided cells has focused on not feeding oxygen to the cell. This can be functional by the modification of the reaction system, at this respect a reactor with rotating disk anodes [58] and other possibility is with a jet aerator system [60] which can be produced until $960 \mathrm{mg} / \mathrm{L}$.

In order to increase by ten times the concentration of hydrogen peroxide by an electrochemical method, the cell can be improved coupling three electrodes separated by a membrane [66, 67], each compartment is called catholyte (or cathodic cell) and anolyte (or anodic cell). It is noted that in this variant, the hydrogen peroxide concentration is almost $10,000 \mathrm{mg} / \mathrm{L}$ (see Table 5).

$\mathrm{H}_{2} \mathrm{O}_{2}$ can also be produced in situ by photocatalysis. Considering this, essentially there are two ways to generate hydrogen peroxide by photocatalysis. Both are based on the use of a semiconductor photocatalyst to generate hydrogen peroxide by two-electron reduction of $\mathrm{O}_{2}$ [68]. The most employed method is using an organic reducer like ethanol, methanol, oxalate, or other similar organic compounds, which is required as a sacrificial electron source; in contrast there are undesirable reactions [68-70]. In this case, alcohols are employed to reduce the probability of electron-hole recombination [71]. In order to decrease the concentration of by-products and eliminate the use of organic reducers, recently some studies report the use of catalysts that can produce hydrogen peroxide only by water oxidation [56,71]. Table 6 shows the concentrations obtained by several catalysts, taking into account the two methods mentioned above. It can be observed that the employed volume is rather low when comparing with the electrochemical method. 
Table $6 \mathrm{H}_{2} \mathrm{O}_{2}$ generated by photochemical methods

\begin{tabular}{|c|c|c|c|}
\hline $\begin{array}{l}\mathrm{H}_{2} \mathrm{O}_{2} \text { photo- } \\
\text { catalyzed } \\
(\mathrm{mg} / \mathrm{L})\end{array}$ & Reaction conditions & Observations & References \\
\hline 115.64 & $\begin{array}{l}\text { Photoirradation: } \\
\lambda>280 \mathrm{~nm} \\
\text { Catalyst: } \mathrm{Au}_{0.1} \mathrm{Ag}_{0.4} / \mathrm{Ti} \\
\mathrm{O}_{2} \\
\text { Catalyst dosage: } 5 \mathrm{mg} \\
\text { System: ethanol/water } \\
{[4 / 96] \mathrm{v} / \mathrm{v}} \\
V=5 \mathrm{~mL} \\
\text { Time: } 12 \mathrm{~h}\end{array}$ & $\begin{array}{l}266 \mu \mathrm{mol} \text { of } \mathrm{CH}_{3} \mathrm{CHO} 13.8 \mathrm{~nm} \text {, metal } \\
\text { particle size }\end{array}$ & {$[22]$} \\
\hline 2.14 & $\begin{array}{l}\text { Photoirradation: } \\
100 \mathrm{~mW} / \mathrm{cm}^{2} \\
\text { Catalyst: composite } \\
\text { MMO@ } \mathrm{C}_{3} \mathrm{~N}_{4} \\
\text { Catalyst dosage: } 1 \mathrm{~g} / \mathrm{L} \\
\text { pH } 3 \\
\text { Time: } 90 \mathrm{~min}\end{array}$ & $\begin{array}{l}\text { Production only from water and } \\
\text { oxygen }\end{array}$ & [71] \\
\hline 3,741 & $\begin{array}{l}\text { Photoirradation: } \\
\lambda<420 \mathrm{~nm}, \mathrm{Xe} \text { lamp } \\
300 \mathrm{~W} \\
\text { Catalyst: } \mathrm{Cd}_{3}\left(\mathrm{C}_{3} \mathrm{~N}_{3} \mathrm{~S}_{3}\right)_{2} \\
\text { Catalyst dosage: } 80 \mathrm{mg} / \mathrm{L} \\
V=20 \mathrm{~mL} \\
\text { System: methanol/water } \\
{[1 / 19] \mathrm{v} / \mathrm{v}} \\
\mathrm{pH} 2.8 \\
\text { Time: } 4 \mathrm{~h} \\
\end{array}$ & Visible light illumination & {$[70]$} \\
\hline 204 & $\begin{array}{l}\text { Photoirradiation: } \\
\lambda>420 \mathrm{~nm} \text { Xe lamp } \\
2 \mathrm{~kW} \\
\text { Catalyst: graphite carbon } \\
\text { nitride } \mathrm{g}^{-} \mathrm{C}_{3} \mathrm{~N}_{4} \\
\text { Catalyst dosage: } 20 \mathrm{mg} \\
V=5 \mathrm{~mL} \\
\text { System: methanol/water } \\
\text { [9/1] v/v } \\
\text { Time: } 12 \mathrm{~h}\end{array}$ & $\begin{array}{l}\text { The catalyst can also be activated by } \\
\text { sunlight. Inexpensive metal-free } \\
\text { photocatalyst }\end{array}$ & {$[72]$} \\
\hline 54.42 & $\begin{array}{l}\text { Photoirradation: } 0.56 \mathrm{~W} / \\
\mathrm{cm}^{2} \lambda: 420 \mathrm{~nm} \text { Xe lamp } \\
300 \mathrm{~W} \\
\text { Catalyst: graphite carbon } \\
\text { nitride g- } \mathrm{C}_{3} \mathrm{~N}_{4} \\
\text { Catalyst dosage: } 50 \mathrm{mg} \\
V=50 \mathrm{~mL} \\
\text { Time: } 120 \mathrm{~min}\end{array}$ & $\begin{array}{l}\text { Production only from water and } \\
\text { oxygen }\end{array}$ & {$[56]$} \\
\hline
\end{tabular}


Moreover, the catalyst dosage is too high, so in most of the cases, the catalyst can be activated by sunlight. In fact, working volumes at pilot scale are not reported, and this suggests this method requires further improvement in order to be applied at larger scale.

\subsection{Pharmaceuticals Removed by Fenton}

Despite the drawbacks implicit in this process, this has been successfully applied to the removal of pharmaceutical compounds. Table 7 summarizes some applications in real and synthetic effluents. In this process the catalyst can be homogeneous or heterogeneous. In the former case, the typical source of $\mathrm{Fe}^{2+}$ is the commercial salt $\mathrm{FeSO}_{4}$ or $\mathrm{FeSO}_{4} \cdot 7 \mathrm{H}_{2} \mathrm{O}$ [73-76]. One of the major problems related to homogeneous Fenton is the high concentrations of $\mathrm{Fe}^{n+}$ ions (in order of $20-80 \mathrm{mg} / \mathrm{L}$ ) that need the process for an efficient removal of pollutant. The acceptable discharge to the environment is only of $2 \mathrm{mg} / \mathrm{L}$ [81]. In homogeneous systems, the separation of the catalyst is rather difficult. Nevertheless, $\mathrm{FeSO}_{4}$ has also been applied at industrial scale $(250 \mathrm{~L})$ in the removal of berberine employing real wastewater, obtaining good results and mineralization almost complete at low concentrations and only partial for a high pollutant load [75]. Considering this and meanly the recovery of catalyst, a significant amount of research has focused on the use of heterogeneous catalysts like iron oxides, iron doped with other metals, supported iron, and other approaches. The aim of this method is to facilitate the separation of iron ions after the treatment [82]. In both catalytic systems, the key parameter is the molar ratio $\mathrm{H}_{2} \mathrm{O}_{2} / \mathrm{Fe}^{2+}$. When this ratio is higher than 10 , the removal efficiency decays by the scavenging effect of hydroxyl radical [83]. Some catalysts, like nanostructured, provide more surface area and active sites which decompose hydrogen peroxide [84]. Other important parameter in heterogeneous catalysis is the decrease of the catalyst activity after a long time of use. This loss of activity can be mainly due to the catalyst leaching. This, however, promotes homogeneous fenton. Nevertheless, heterogenous fenton allows the re-use of the catalyst. Moreover, unlike homogeneous Fenton, the heterogeneous one can be conducted under near neutral $\mathrm{pH}$ [78]. The main limitation for heterogeneous Fenton is the catalyst synthesis, since in the most cases this is only a few grams. In the investigations shown in Table 7, there is only one investigation at pilot scale employing a catalyst-denominated modified polyacrylonitrile obtaining a poor removal of initial concentration.

As can be observed in most of the cases, the pollutant mineralization is only partial, and the treatment time sometimes is rather large. This has motivated the combination of this process with others like photochemical and electrochemical. These so modified processes are called photo-Fenton and electro-Fenton [46]. 
Table 7 Examples of pharmaceutical compounds removed by Fenton

\begin{tabular}{|c|c|c|c|c|}
\hline $\begin{array}{l}\text { Pharmaceutical } \\
\text { compound }\end{array}$ & Reaction conditions & Removal (\%) & Observations & References \\
\hline $\begin{array}{l}\text { Acetaminophen, } \\
\text { atenolol, atrazine, } \\
\text { carbamazepine, } \\
\text { metoprolol, Dilan- } \\
\text { tin, DEE, } \\
\text { diclofenac, } \\
\text { pentoxifylline, } \\
\text { oxybenzone, caf- } \\
\text { feine, fluoxetine, } \\
\text { gemfibrozil, ibu- } \\
\text { profen, iopromide, } \\
\text { naproxen, propran- } \\
\text { olol, sulfamethox- } \\
\text { azole, and } \\
\text { trimethoprim }\end{array}$ & $\begin{array}{l}\text { Catalyst: } \mathrm{Fe}^{2+} \\
\text { Catalyst dosage: } \\
20 \mathrm{mg} / \mathrm{L} \\
{\left[\mathrm{H}_{2} \mathrm{O}_{2} / \mathrm{Fe}^{2+}\right]: 2.5 \mathrm{M}} \\
\text { ratio } \\
\mathrm{pH}: 3 \\
\mathrm{C}_{0}: 9.6 \mathrm{mg} / \mathrm{L}\left[\mathrm{C}_{0}:\right. \\
1 \mu \mathrm{g} / \mathrm{L} \text { for each } \\
\text { compound }] \\
\text { Time: } 30 \mathrm{~min}\end{array}$ & $\begin{array}{l}100 \\
\text { HPLC/LC-MS } \\
\text { and GC } \\
\text { TOC } \sim 30\end{array}$ & $\begin{array}{l}\text { Not eliminated, } \\
\text { atrazine and } \\
\text { iopromide }\end{array}$ & [73] \\
\hline $\begin{array}{l}\text { Sulfamethoxazole/ } \\
\text { acetaminophen }\end{array}$ & $\begin{array}{l}\text { Catalyst: } \mathrm{Fe}^{2+} \\
{\left[\mathrm{H}_{2} \mathrm{O}_{2}\right]: 1.3 \times 10^{-4}} \\
\mathrm{~mol} / \mathrm{L} \\
V: 1 \mathrm{~L} \\
{\left[\mathrm{H}_{2} \mathrm{O}_{2} / \mathrm{Fe}^{2+}\right]: 5 \mathrm{M}} \\
\text { ratio } \\
\mathrm{C}_{0}: 11.88 \mathrm{mg} / \mathrm{L} \\
\text { Time: } 120 \mathrm{~min}\end{array}$ & TOC: 11.3 & $\begin{array}{l}\text { In situ genera- } \\
\text { tion of } \mathrm{H}_{2} \mathrm{O}_{2} \text { by } \\
\text { previous ozona- } \\
\text { tion process }\end{array}$ & [74] \\
\hline Berberine & $\begin{array}{l}\text { Catalyst: } \mathrm{FeSO}_{4} \\
V: 250 \mathrm{~L} \\
{\left[\mathrm{Fe}^{2+} / \mathrm{H}_{2} \mathrm{O}_{2}\right]: 0.1 \mathrm{M}} \\
\text { ratio } \\
\mathrm{pH}: 3 \\
\mathrm{C}_{0}: 4,061 \mathrm{mg} / \mathrm{L} \\
\text { high concentration } \\
\mathrm{C}_{0}: 709 \mathrm{mg} / \mathrm{L} \text { low } \\
\text { concentration } \\
\text { Volumetric flow } \\
\text { rate: } 100 \mathrm{~L} / \mathrm{h} \\
\text { Time: } 60 \mathrm{~min} \\
\text { (hydraulic retention } \\
\text { time) }\end{array}$ & $\begin{array}{l}\text { COD: } 35.6 \text { for } \\
\text { high concentra- } \\
\text { tion } \\
\text { COD: } 91.4 \% \text { for } \\
\text { low concentration }\end{array}$ & $\begin{array}{l}\text { Industrial scale } \\
\text { BOD }_{5} / \mathrm{COD}: \\
0.3 \text {, increased } \\
\text { biodegradability } \\
\text { Real wastewater } \\
\text { with pH } \\
\text { extremely low } \\
0.06-0.09\end{array}$ & [75] \\
\hline $\begin{array}{l}\text { Carbamazepine } \\
(\mathrm{CBZ})\end{array}$ & $\begin{array}{l}\text { Catalyst: } \\
\mathrm{FeSO}_{4} \cdot 7 \mathrm{H}_{2} \mathrm{O} \\
V: 100 \mathrm{~mL} \\
{\left[\mathrm{H}_{2} \mathrm{O}_{2}\right]: 8.5 \mathrm{~g} / \mathrm{L}} \\
{\left[\mathrm{Fe}^{2+} / \mathrm{H}_{2} \mathrm{O}_{2}\right]: 1 \mathrm{M}} \\
\text { ratio } \\
\mathrm{pH}: 3.5 \\
\mathrm{C}_{0}: 442 \mathrm{mg} / \mathrm{L} \\
\text { Time } \sim 25 \mathrm{~min}\end{array}$ & HPLC: 49.49 & $\begin{array}{l}\text { Industrial } \\
\text { wastewater } \\
\text { Treatment } \\
\text { followed by } \\
\text { GAC obtaining } \\
99.51 \% \text { of } \\
\text { removal }\end{array}$ & [76] \\
\hline
\end{tabular}


Advanced Oxidation Processes: Ozonation and Fenton Processes Applied to...

Table 7 (continued)

\begin{tabular}{|c|c|c|c|c|}
\hline $\begin{array}{l}\text { Pharmaceutical } \\
\text { compound }\end{array}$ & Reaction conditions & Removal (\%) & Observations & References \\
\hline $\begin{array}{l}\text { Steroid hormones, } \\
\text { personal care prod- } \\
\text { ucts, and } \\
\text { pharmaceuticals }\end{array}$ & $\begin{array}{l}\text { Catalyst: PAN } \\
\text { (modified polyacry- } \\
\text { lonitrile) } \\
V: 31.34 \mathrm{~L} \\
{\left[\mathrm{H}_{2} \mathrm{O}_{2}\right]: 200 \mathrm{mg} / \mathrm{L}} \\
\text { Volumetric flow } \\
\text { rate: } 10.6 \mathrm{~L} / \mathrm{h} \\
\mathrm{pH} \text { natural of } \\
\text { wastewater } \\
\mathrm{C}_{0}: 6-11.08 \mathrm{mg} / \mathrm{L} \\
\text { Time } \sim 180 \mathrm{~min}\end{array}$ & $\begin{array}{l}\text { LC-MS/MS: }>90 \\
\text { (hormones) } \\
\text { LC-MS/MS: }>40 \\
\text { (pharmaceuticals) } \\
\text { TOC: } 30-40\end{array}$ & $\begin{array}{l}\text { Pilot plant. } \\
\text { Municipal } \\
\text { wastewater } \\
\text { The catalyst not } \\
\text { needs ranges of } \\
\text { pH 2-4 } \\
\text { Reported } \\
\text { leaching is less } \\
\text { than } 4 \% \\
\text { BOD reduce to } \\
\text { less than } 1 \mathrm{mg} / \mathrm{L}\end{array}$ & {$[77]$} \\
\hline Diclofenac & $\begin{array}{l}\text { Catalyst: Fe-doped } \\
\mathrm{CeO}_{2} \\
\text { Catalyst dosage: } \\
0.5 \mathrm{~g} / \mathrm{L} \\
V: 150 \mathrm{~mL} \\
{\left[\mathrm{H}_{2} \mathrm{O}_{2}\right]: 10 \mathrm{mM}} \\
\mathrm{pH} 5 \\
\mathrm{C}_{0}: 20 \mathrm{mg} / \mathrm{L} \\
\text { Time: } 40 \mathrm{~min}\end{array}$ & HPLC: 85.25 & $\begin{array}{l}\text { Removal of } \\
2.2 \% \text { only with } \\
\mathrm{H}_{2} \mathrm{O}_{2} \text { after } \\
40 \text { min }\end{array}$ & {$[78]$} \\
\hline Paracetamol & $\begin{array}{l}\text { Catalyst: MGN1 } \\
\left(\mathrm{Fe}_{3} \mathrm{O}_{4} \text { powder }\right. \\
<50 \mathrm{~nm}) \\
\text { MGN2 }\left(\mathrm{Fe}_{3} \mathrm{O}_{4}\right. \\
\text { powder }<5 \mathrm{~nm}) \\
\mathrm{MGM}\left(\mathrm{Fe}_{3} \mathrm{O}_{4} \text { pow- }\right. \\
\text { der }<50 \mathrm{~nm}) \\
\text { Catalyst dosage: } \\
6 \mathrm{~g} / \mathrm{L} \\
\mathrm{V}: 650 \mathrm{~mL} \\
{\left[\mathrm{H}_{2} \mathrm{O}_{2}\right]: 153 \mathrm{mM}} \\
\mathrm{pH} 2.6 \\
\mathrm{C}_{0}: 100 \mathrm{mg} / \mathrm{L} \\
\text { Time: } 5 \mathrm{~h}\end{array}$ & $\begin{array}{l}\text { TOC: } 43 \text { (MGN1) } \\
\text { TOC: } 34 \text { (MGN2) } \\
\text { TOC: } 39 \text { (MGM) }\end{array}$ & $\begin{array}{l}\text { With three cata- } \\
\text { lysts, the total } \\
\text { removal of } \\
\text { paracetamol } \\
\text { was obtained } \\
\text { Without catalyst } \\
\text { there is no } \\
\text { removal }\end{array}$ & [79] \\
\hline Ofloxacin & $\begin{array}{l}\text { Catalyst: alginate } \\
\text { iron (4\%) } \\
\text { Catalyst dosage: } \\
400 \mathrm{mg} / \mathrm{L} \\
V: 100 \mathrm{~mL} \\
{\left[\mathrm{H}_{2} \mathrm{O}_{2}\right]: 4.067 \mathrm{mM}} \\
\mathrm{pH} 3 \\
\mathrm{C}_{0}: 30 \mathrm{mg} / \mathrm{L} \\
\text { Time: } 180 \mathrm{~min}\end{array}$ & UV: 98 & $\begin{array}{l}\text { After three suc- } \\
\text { cessive runs, } \\
\text { activity } \\
\text { decreases only } \\
\text { around } 10 \%\end{array}$ & {$[80]$} \\
\hline
\end{tabular}




\section{Conclusions}

Ozonation and Fenton are processes that are capable to remove $100 \%$ of a wide variety of pharmaceutical compounds from wastewater. These processes fail, however, on achieving full mineralization, and this may lead to worsen the problem from a toxicological point of view. Therefore such processes should be combined with toxicological analysis, either theoretical or experimental, of the treated effluents. The main reaction variables affecting the efficiency of such processes are $\mathrm{pH}$, ozone, and $\mathrm{H}_{2} \mathrm{O}_{2}$ concentration, reactor design, and the presence of catalysts, light, or electrolysis.

\section{References}

1. Brillas E, Huitle CAM (2011) Synthetic diamond films: preparation, electrochemistry, characterization and applications. Wiley, Hoboken

2. Gottschalk C, Libra JA, Saupe A (2009) Ozonation of water and waste water: a practical guide to understanding ozone and its applications. Wiley, Hoboken

3. Alpatova AL, Davies SH, Masten SJ (2013) Hybrid ozonation-ceramic membrane filtration of surface waters: the effect of water characteristics on permeate flux and the removal of DBP precursors, dicloxacillin and ceftazidime. Sep Purif Technol 107:179-186

4. Borowska E, Bourgin M, Hollender J et al (2016) Oxidation of cetirizine, fexofenadine and hydrochlorothiazide during ozonation: kinetics and formation of transformation products. Water Res 94:350-362

5. Tay KS, Madehi N (2015) Ozonation of ofloxacin in water: by-products, degradation pathway and ecotoxicity assessment. Sci Total Environ 520:23-31

6. Huang G, Pan F, Fan G, Liu G (2016) Application of heterogeneous catalytic ozonation as a tertiary treatment of effluent of biologically treated tannery wastewater. J Environ Sci Health Toxicol Hazard Subst Environ Eng 51:626-633

7. Martins RC, Cardoso M, Dantas RF et al (2015) Catalytic studies for the abatement of emerging contaminants by ozonation. J Chem Technol Biotechnol 90:1611-1618

8. Polat D, Balci I, Özbelge TA (2015) Catalytic ozonation of an industrial textile wastewater in a heterogeneous continuous reactor. J Environ Chem Eng 3:1860-1871

9. Crousier C, Pic J-S, Albet J et al (2016) Urban wastewater treatment by catalytic ozonation. Ozone Sci Eng 38:3-13

10. Chen S-Y, Li Y-M, Lei L-R (2015) Tertiary treatment of paper-making tobacco sheet wastewater via catalytic ozonation with Ti(IV) ions. Huanan Ligong Daxue Xuebao J South China Univ Technol Nat Sci 43:131-139

11. Wang T, Xue L, Brimblecombe P et al (2017) Ozone pollution in China: a review of concentrations, meteorological influences, chemical precursors, and effects. Sci Total Environ 575:1582-1596

12. Lucas MS, Reis NM, Li Puma G (2016) Intensification of ozonation processes in a novel, compact, multi-orifice oscillatory baffled column. Chem Eng J 296:335-339

13. Hewgill MR, Mackley MR, Pandit AB, Pannu SS (1993) Enhancement of gas-liquid mass transfer using oscillatory flow in a baffled tube. Chem Eng Sci 48:799-809

14. Martín del Campo E, Valente JS, Pavón T et al (2011) 4-chlorophenol oxidation photocatalyzed by a calcined $\mathrm{Mg}-\mathrm{Al}-\mathrm{Zn}$ layered double hydroxide in a co-current downflow bubble column. Ind Eng Chem Res 50:11544-11552 
Advanced Oxidation Processes: Ozonation and Fenton Processes Applied to...

15. Ochuma IJ, Fishwick RP, Wood J, Winterbottom JM (2007) Optimisation of degradation conditions of 1,8-diazabicyclo 5.4.0 undec-7-ene in water and reaction kinetics analysis using a cocurrent downflow contactor photocatalytic reactor. Appl Catal B Environ 73 (3-4):259-268

16. Ochuma IJ, Fishwick RP, Wood J, Winterbottoom JM (2007) Photocatalytic oxidation of 2,4,6-trichlorophenol in water using a cocurrent downflow contactor reactor (CDCR). J Hazard Mater 144:627-633

17. Alharbi SK, Price WE, Kang J et al (2016) Ozonation of carbamazepine, diclofenac, sulfamethoxazole and trimethoprim and formation of major oxidation products. Desalin Water Treat 57:29340-29351

18. Zhao Y, Kuang J, Zhang S et al (2017) Ozonation of indomethacin: kinetics, mechanisms and toxicity. J Hazard Mater 323:460-470

19. Rodríguez EM, Márquez G, León EA et al (2013) Mechanism considerations for photocatalytic oxidation, ozonation and photocatalytic ozonation of some pharmaceutical compounds in water. J Environ Manag 127:114-124

20. Gimeno O, García-Araya JF, Beltrán FJ et al (2016) Removal of emerging contaminants from a primary effluent of municipal wastewater by means of sequential biological degradationsolar photocatalytic oxidation processes. Chem Eng J 290:12-20

21. Gomes DS, Gando-Ferreira LM, Quinta-Ferreira RM, Martins RC (2017) Removal of sulfamethoxazole and diclofenac from water: strategies involving $\mathrm{O}_{3}$ and $\mathrm{H}_{2} \mathrm{O}_{2}$. Environ Technol 1-42. https://doi.org/10.1080/09593330.2017.1335351

22. Kermani M, Farzadkia M, Esrafili A et al (2016) Removal of catechol from aqueous solutions using catalytic ozonation by magnetic nanoparticles of iron oxide doped with silica and titanium dioxide: a kinetic study. J Mazandaran Univ Med Sci 26:139-154

23. Oropesa AL, Novais SC, Lemos MFL et al (2017) Oxidative stress responses of Daphnia magna exposed to effluents spiked with emerging contaminants under ozonation and advanced oxidation processes. Environ Sci Pollut Res 24:1735-1747

24. Prado M, Borea L, Cesaro A et al (2017) Removal of emerging contaminant and fouling control in membrane bioreactors by combined ozonation and sonolysis. Int Biodeterior Biodegrad 119:577-586

25. Salimi M, Esrafili A, Gholami M et al (2017) Contaminants of emerging concern: a review of new approach in AOP technologies. Environ Monit Assess 189(8):414

26. Nawrocki J (2013) Catalytic ozonation in water: controversies and questions. Discussion paper. Appl Catal B Environ 142-143:465-471

27. Nawrocki J, Kasprzyk-Hordern B (2010) The efficiency and mechanisms of catalytic ozonation. Appl Catal B Environ 99:27-42

28. Martínez-Huitle CA, Rodrigo MA, Sirés I, Scialdone O (2015) Single and coupled electrochemical processes and reactors for the abatement of organic water pollutants: a critical review. Chem Rev 115:13362-13407

29. Liu Z-Q, Ma J, Cui Y-H et al (2011) Factors affecting the catalytic activity of multi-walled carbon nanotube for ozonation of oxalic acid. Sep Purif Technol 78:147-153

30. Dai Q, Wang J, Yu J et al (2014) Catalytic ozonation for the degradation of acetylsalicylic acid in aqueous solution by magnetic $\mathrm{CeO}_{2}$ nanometer catalyst particles. Appl Catal B Environ 144:686-693

31. Qin H, Chen H, Zhang X et al (2014) Efficient degradation of fulvic acids in water by catalytic ozonation with $\mathrm{CeO}_{2}$ /AC. J Chem Technol Biotechnol 89:1402-1409

32. Faria PCC, Órfão JJM, Pereira MFR (2009) Activated carbon and ceria catalysts applied to the catalytic ozonation of dyes and textile effluents. Appl Catal B Environ 88:341-350

33. Buxton GV, Greenstock CL, Helman WP, Ross AB (1988) Critical review of rate constants for reactions of hydrated electrons, hydrogen atoms and hydroxyl radicals $\left({ }^{\circ} \mathrm{OH} / \mathrm{O}^{-}\right)$in aqueous solution. J Phys Chem Ref Data 17:513-886 
34. Yin R, Guo W, Zhou X et al (2016) Enhanced sulfamethoxazole ozonation by noble metal-free catalysis based on magnetic $\mathrm{Fe}_{3} \mathrm{O}_{4}$ nanoparticles: catalytic performance and degradation mechanism. RSC Adv 6:19265-19270

35. Qi F, Chu W, Xu B (2016) Comparison of phenacetin degradation in aqueous solutions by catalytic ozonation with $\mathrm{CuFe} 2 \mathrm{O} 4$ and its precursor: surface properties, intermediates and reaction mechanisms. Chem Eng J 284:28-36

36. Bai Z, Yang Q, Wang J (2016) Catalytic ozonation of sulfamethazine antibiotics using $\mathrm{Ce} 0.1 \mathrm{Fe} 0.9 \mathrm{OOH}$ : catalyst preparation and performance. Chemosphere 161:174-180. https:// doi.org/10.1016/j.chemosphere.2016.07.012

37. Bing J, Hu C, Nie Y et al (2015) Mechanism of catalytic ozonation in Fe2O3/A12O3@ SBA-15 aqueous suspension for destruction of ibuprofen. Environ Sci Technol 49:1690-1697

38. Aghaeinejad-Meybodi A, Ebadi A, Shafiei S et al (2015) Degradation of antidepressant drug fluoxetine in aqueous media by ozone $/ \mathrm{H}_{2} \mathrm{O}_{2}$ system: process optimization using central composite design. Environ Technol 36:1477-1488

39. Li H, Xu B, Qi F et al (2014) Degradation of bezafibrate in wastewater by catalytic ozonation with cobalt doped red mud: efficiency, intermediates and toxicity. Appl Catal B Environ 152-153:342-351

40. Hollender J, Zimmermann SG, Koepke S et al (2009) Elimination of organic micropollutants in a municipal wastewater treatment plant upgraded with a full-scale post-ozonation followed by sand filtration. Environ Sci Technol 43:7862-7869

41. Mashayekh-Salehi A, Moussavi G, Yaghmaeian K (2017) Preparation, characterization and catalytic activity of a novel mesoporous nanocrystalline $\mathrm{MgO}$ nanoparticle for ozonation of acetaminophen as an emerging water contaminant. Chem Eng J 310:157-169

42. Jin X, Peldszus S, Huck PM (2012) Reaction kinetics of selected micropollutants in ozonation and advanced oxidation processes. Water Res 46:6519-6530

43. Amado-Piña D, Roa-Morales G, Barrera-Díaz C et al (2017) Synergic effect of ozonation and electrochemical methods on oxidation and toxicity reduction: phenol degradation. Int Mex Congr Chem React Eng 198:82-90

44. Xu B, Qi F, Sun D et al (2016) Cerium doped red mud catalytic ozonation for bezafibrate degradation in wastewater: efficiency, intermediates, and toxicity. Chemosphere 146:22-31

45. Brillas E, Sirés I, Oturan MA (2009) Electro-Fenton process and related electrochemical technologies based on Fenton's reaction chemistry. Chem Rev 109:6570-6631

46. Oturan MA, Aaron J-J (2014) Advanced oxidation processes in water/wastewater treatment: principles and applications. A review. Crit Rev Environ Sci Technol 44:2577-2641

47. Bokare AD, Choi W (2014) Review of iron-free Fenton-like systems for activating $\mathrm{H}_{2} \mathrm{O}_{2}$ in advanced oxidation processes. J Hazard Mater 275:121-135

48. Pang S-Y, Jiang J, Ma J (2011) Oxidation of sulfoxides and arsenic(III) in corrosion of nanoscale zero valent iron by oxygen: evidence against ferryl ions ( $\mathrm{Fe}(\mathrm{IV}))$ as active intermediates in fenton reaction. Environ Sci Technol 45:3179-3180

49. De Laat HJG (1999) Catalytic decomposition of hydrogen peroxide by Fe(III) in homogeneous aqueous solution: mechanism and kinetic modeling. Environ Sci Technol 33:2726-2732

50. Novoa-Luna KA, Mendoza-Zepeda A, Natividad R et al (2016) Biological hazard evaluation of a pharmaceutical effluent before and after a photo-Fenton treatment. Sci Total Environ 569:830-840

51. Bernal M, Romero R, Roa G et al (2013) Ozonation of indigo carmine catalyzed with Fe-pillared clay. Int J Photoenergy 2013:7

52. Santana-Martínez G, Roa-Morales G, Martin del Campo E et al (2016) Electro-Fenton and electro-Fenton-like with in situ electrogeneration of $\mathrm{H}_{2} \mathrm{O}_{2}$ and catalyst applied to 4-chlorophenol mineralization. Electrochim Acta 195:246-256

53. Campos-Martin JM, Blanco-Brieva G, Fierro JL (2006) Hydrogen peroxide synthesis: an outlook beyond the anthraquinone process. Angew Chem Int Ed 45:6962-6984

54. Wernimont E, Ventura M, Garboden G, Mullens P (1999) Past and present uses of rocket grade hydrogen peroxide. General Kinetics, LLC Aliso Viejo, CA 92656 
Advanced Oxidation Processes: Ozonation and Fenton Processes Applied to...

55. Moreira FC, Boaventura RAR, Brillas E, Vilar VJP (2017) Electrochemical advanced oxidation processes: a review on their application to synthetic and real wastewaters. Appl Catal B Environ 202:217-261

56. Yang L, Dong G, Jacobs DL et al (2017) Two-channel photocatalytic production of $\mathrm{H}_{2} \mathrm{O}_{2}$ over g- $\mathrm{C}_{3} \mathrm{~N}_{4}$ nanosheets modified with perylene imides. J Catal 352:274-281

57. Isarain-Chávez E, Martínez-Huitle CA, Peralta-Hernández JM, De la Rosa C (2013) On-site hydrogen peroxide production at pilot flow plant: application to electro-Fenton process. Int $\mathrm{J}$ Electrochem Sci 8:3084-3094

58. Yu F, Zhou M, Zhou L, Peng R (2014) A novel electro-Fenton process with $\mathrm{H}_{2} \mathrm{O}_{2}$ generation in a rotating disk reactor for organic pollutant degradation. Environ Sci Technol Lett 1:320-324

59. Yu F, Zhou M, Yu X (2015) Cost-effective electro-Fenton using modified graphite felt that dramatically enhanced on $\mathrm{H}_{2} \mathrm{O}_{2}$ electro-generation without external aeration. Electrochim Acta 163:182-189

60. Pérez JF, Llanos J, Sáez C et al (2016) Electrochemical jet-cell for the in-situ generation of hydrogen peroxide. Electrochem Commun 71:65-68

61. Assumpção M, Moraes A, De Souza R et al (2012) Low content cerium oxide nanoparticles on carbon for hydrogen peroxide electrosynthesis. Appl Catal A Gen 411:1-6

62. Silva FL, Reis RM, Barros WRP et al (2014) Electrogeneration of hydrogen peroxide in gas diffusion electrodes: application of iron (II) phthalocyanine as a modifier of carbon black. J Electroanal Chem 722-723:32-37

63. Peralta E, Natividad R, Roa G et al (2013) A comparative study on the electrochemical production of $\mathrm{H}_{2} \mathrm{O}_{2}$ between BDD and graphite cathodes. Sustain Environ Res 23:259-266

64. Olvera-Vargas H, Oturan N, Oturan MA, Brillas E (2015) Electro-Fenton and solar photoelectro-Fenton treatments of the pharmaceutical ranitidine in pre-pilot flow plant scale. Sep Purif Technol 146:127-135

65. Pérez T, Garcia-Segura S, El-Ghenymy A et al (2015) Solar photoelectro-Fenton degradation of the antibiotic metronidazole using a flow plant with a Pt/air-diffusion cell and a CPC photoreactor. Electrochim Acta 165:173-181

66. Bustos YA, Rangel-Peraza JG, Rojas-Valencia MN et al (2016) Treatment of industrial effluents by electrochemical generation of $\mathrm{H}_{2} \mathrm{O}_{2}$ using an RVC cathode in a parallel plate reactor. Environ Technol 37:815-827

67. Luo H, Li C, Wu C et al (2015) Electrochemical degradation of phenol by in situ electrogenerated and electro-activated hydrogen peroxide using an improved gas diffusion cathode. Electrochim Acta 186:486-493

68. Kato S, Jung J, Suenobu T, Fukuzumi S (2013) Production of hydrogen peroxide as a sustainable solar fuel from water and dioxygen. Energy Environ Sci 6:3756-3764

69. Tsukamoto D, Shiro A, Shiraishi Y et al (2012) Photocatalytic $\mathrm{H}_{2} \mathrm{O}_{2}$ production from ethanol/ $\mathrm{O}_{2}$ system using $\mathrm{TiO}_{2}$ loaded with $\mathrm{Au}-\mathrm{Ag}$ bimetallic alloy nanoparticles. ACS Catal 2:599-603

70. Zhuang $\mathrm{H}$, Yang L, Xu J et al (2015) Robust photocatalytic $\mathrm{H}_{2} \mathrm{O}_{2}$ production by octahedral $\mathrm{Cd}_{3}\left(\mathrm{C}_{3} \mathrm{~N}_{3} \mathrm{~S}_{3}\right)_{2}$ coordination polymer under visible light. Sci Rep 5:16947

71. Wang R, Pan K, Han D et al (2016) Solar-driven $\mathrm{H}_{2} \mathrm{O}_{2}$ generation from $\mathrm{H}_{2} \mathrm{O}$ and $\mathrm{O}_{2}$ using earth-abundant mixed-metal oxide@carbon nitride photocatalysts. ChemSusChem 9:2470-2479

72. Shiraishi Y, Kanazawa S, Sugano Y et al (2014) Highly selective production of hydrogen peroxide on graphitic carbon nitride (g-C3N4) photocatalyst activated by visible light. ACS Catal 4:774-780

73. Li W, Nanaboina V, Zhou Q, Korshin GV (2012) Effects of Fenton treatment on the properties of effluent organic matter and their relationships with the degradation of pharmaceuticals and personal care products. Water Res 46:403-412

74. Aguinaco A, Beltrán FJ, Sagasti JJP, Gimeno O (2014) In situ generation of hydrogen peroxide from pharmaceuticals single ozonation: a comparative study of its application on Fenton like systems. Chem Eng J 235:46-51 
75. Cui X, Zeng P, Qiu G et al (2015) Pilot-scale treatment of pharmaceutical berberine wastewater by Fenton oxidation. Environ Earth Sci 73:4967-4977

76. Dwivedi K, Morone A, Chakrabarti T, Pandey RA (2016) Evaluation and optimization of Fenton pretreatment integrated with granulated activated carbon (GAC) filtration for carbamazepine removal from complex wastewater of pharmaceutical industry. J Environ Chem Eng. https://doi.org/10.1016/j.jece.2016.12.054

77. Chi GT, Churchley J, Huddersman KD (2013) Pilot-scale removal of trace steroid hormones and pharmaceuticals and personal care products from municipal wastewater using a heterogeneous fenton's catalytic process. Int J Chem Eng. https://doi.org/10.1155/2013/760915

78. Chong S, Zhang G, Zhang N et al (2016) Preparation of FeCeOx by ultrasonic impregnation method for heterogeneous Fenton degradation of diclofenac. Ultrason Sonochem 32:231-240

79. Velichkova F, Julcour-Lebigue C, Koumanova B, Delmas H (2013) Heterogeneous Fenton oxidation of paracetamol using iron oxide (nano)particles. J Environ Chem Eng 1:1214-1222

80. Titouhi H, Belgaied J-E (2016) Heterogeneous Fenton oxidation of ofloxacin drug by iron alginate support. Environ Technol 37:2003-2015

81. Mirzaei A, Chen Z, Haghighat F, Yerushalmi L (2017) Removal of pharmaceuticals from water by homo/heterogonous Fenton-type processes - a review. Chemosphere 174:665-688

82. Arzate-Salgado S-Y, Morales-Pérez A-A, Solís-López M, Ramírez-Zamora R-M (2016) Evaluation of metallurgical slag as a Fenton-type photocatalyst for the degradation of an emerging pollutant: diclofenac. Catal Today 266:126-135

83. Bautitz IR, Nogueira RFP (2007) Degradation of tetracycline by photo-Fenton process-solar irradiation and matrix effects. J Photochem Photobiol Chem 187:33-39

84. Sun S-P, Lemley AT (2011) P-nitrophenol degradation by a heterogeneous Fenton-like reaction on nano-magnetite: process optimization, kinetics, and degradation pathways. J Mol Catal Chem 349:71-79 